\title{
The application of Airborne Laser Scaning for identifying old lignite workings - case study: the mine "Borussia" near Ośno Lubuskie (Western Poland)
}

\author{
Agnieszka Gontaszewska-Piekarz ${ }^{1, *}$, Maria Mrówczyńska ${ }^{1}$ \\ ${ }^{1}$ University of Zielona Góra, Faculty of Civil, Environmental Engineering and Architecture, Zielona \\ Góra, Poland
}

\begin{abstract}
The paper presents the possibilities of using data obtained by airborne laser scanning for identifying areas where lignite used to be mined. The technology of airborne laser scanning presented in the paper as and its results have a vast potential in terms of identifying local terrain deformations. The paper also presents the history of lignite mining in the region of Ośno Lubuskie (the north-west of Ziemia Lubuska - western Poland). It describes underground mining in complicated geological conditions (glaciotectonic deformations). The paper is supplemented with historical maps showing the locations of the mines
\end{abstract}

Keywords: Airborne Laser Scanning, lignite underground mining, terrain deformation

\section{Introduction}

Lignite was mined in the region of Ośno Lubuskie in the years 1850-1962. There were several dozen mines, most of them operated for a short time and on a small area. In the whole area of Ziemia Lubuska and Lower Silesia there were mostly underground mines. This was due to the geological structure of the deposits (glaciotectonic disturbances) and their irregular location, which made open pit mining unprofitable.

The deposits were mined using the retreat mining method, the workings were not filled, only the shafts were filled, which resulted in different kinds of sinkholes on the ground surface. Those sinkholes appeared mostly during mining activities and shortly after they had been finished. It is possible to assume that in most cases the ground settled directly after the mining activities in a particular mining area had been finished.

The deformations over the old workings can be clearly seen in the open, whereas in woods, in particular in the areas where mining activities were finished in the 19th century, they are more difficult to identify.

* Corresponding author: a.gontaszewska@ib.uz.zgora.pl 
In the case of the mines which were closed down before WW2, there is often lack of basic information, e.g. about the mining areas. Therefore, data obtained by airborne scanning can be used. Data obtained in this way enable building high resolution models as well as separating from the cloud of points the information that refers to the terrain cover e.g. buildings and foliage, which makes it possible to build a real terrain model. This is particularly useful for recognizing underground post-lignite mining areas, which at present are located in forest areas [1].

\section{Lignite mining near Ośno Lubuskie}

The history of mining near Ośno Lubuskie can be traced back on the basis of rather rudimentary archive materials (mining licences, drawings of mining areas from the State Mining Authority), geological documents and mining maps, which are dispersed over different archives.

There are very few documents (geological or historical) with at least any mention of the mines near Ośno Lubuskie. A paper from 1852 includes descriptions of drilling profiles; the author also mentions several mines which operated at that time [2]. A description of lignite mining in Brandenburg, including the area near Ośno Lubuskie, can be found in a book by Cramer [3]. The mines of this region are also mentioned in the most important German handbooks [4,5]. In Polish post WW2 literature there are only brief descriptions (based on German materials) [6,7,8]. The most accurate description of lignite mining near Ośno Lubuskie so far can be found in the works of the author $[9,10]$.

The oldest records of mining areas in the region discussed refer to the mining area "Carl" in Smogóry from 1851 as well as "Bergsegen" and "Rudolph" from 1856. The mine "Carl" was established on 12 October 1855 [3], it gave rise to the later mine "Oskar". This mine, under the name of "Smogóry", operated until the 1960s.

Like in the other regions of western Poland, as a result of the consolidation of small mines and mining areas, in the 20th century there remained only a few operational mines: "Oskar" in Smogóry, "Eduard" in Długoszyn and "Borussia" in Trześniów (Fig. 1.).

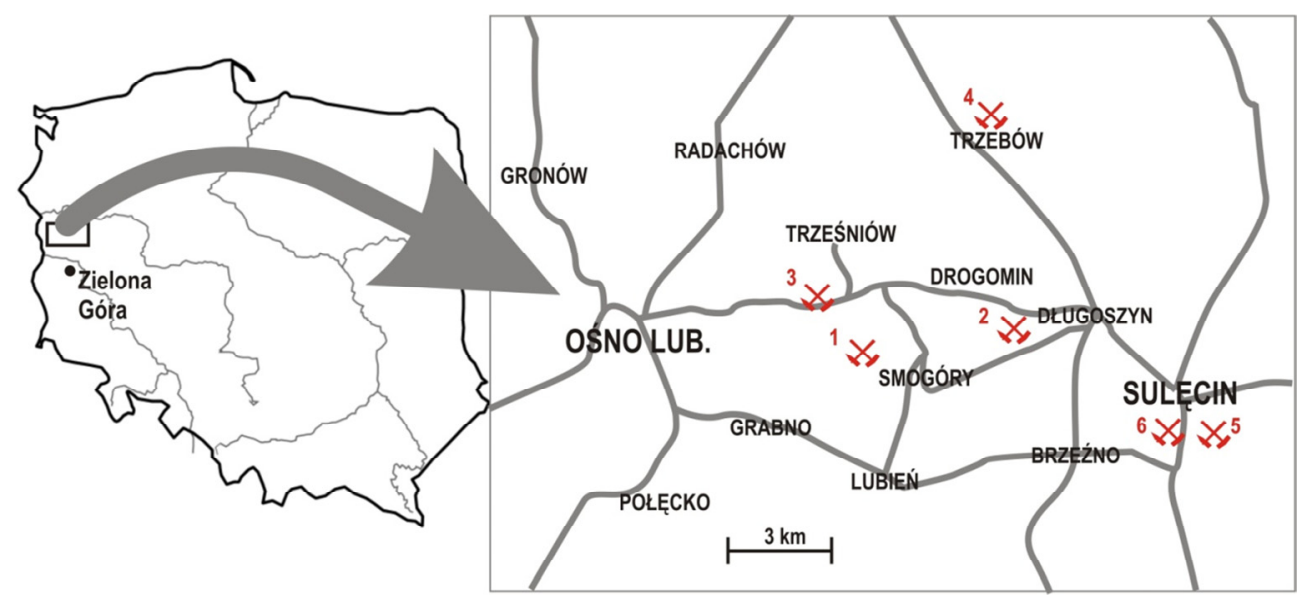

Fig. 1. A map of the most important mines near Ośno Lubuskie. 1 - Oskar/Smogóry, 2 - Eduard/ Długoszyn, 3 - Borussia, 4 - Gute Hoffnung, 5 - Phönix, 6 - Alexander

The lignite deposits mined near Ośno Lubuskie are located in glaciotectonically transformed structures. These processes were particularly intensive in marginal ice zones. The glaciotectonic structures of western Poland appeared mainly during the second 
glaciation of the San river [11] or the second glaciation of the San river and the glaciation of the Oder river [12]. The ice sheet of the subsequent, younger glaciations could have caused further structural changes.

Before WW2 mining activities were conducted only in gaciotectonically disordered structures, where lignite deposits, initially located at great depths, had been "pressed up" towards the surface, which made them accessible for mining.

The deposit mined near Ośno was the "I - środkowopolska grupa pokładów" or "Oberflöz" in Pre-WW2 German literature (now 1. Lausitzer Flöz). This deposit consisted of over a dozen parallel, longitudinal anticlines, which were called saddles. The saddles were partially eroded by the subsequent glaciers and are mostly located under a thin cover of tills. Mining activities were conducted in the places where the deposits were at the shallowest depth, most often in saddle joints (Fig.2). The lignite deposit originally located at about $0 \mathrm{~m}$ above sea level near Ośno Lubuskie was upthrust to about $100 \mathrm{~m}$ above sea level [13]. The deposit was accessible by shafts or descending galleries as well as horizontal galleries, which were also later used for transporting the lignite. The shafts were usually built at the highest points of the saddles. The room and pillar retreat mining method was used. This method consists in removing lignite from rooms and leaving safety pillars of unremoved lignite $[4,14]$. The lignite was transported (usually manually) into the tunnel. Additional ventilation shafts were also built at the end of the tunnels, sometimes also additional transport (mining) shafts.

In the case of steep lignite deposits, which were very common, the mining tunnels were built one above the other, moving downwards. Those tunnels were connected by chutes, which were used to dump lignite to the lower tunnels and then to the main tunnel through which the output was transported to the shaft. The height to which lignite was mined in a room did not usually exceed $5 \mathrm{~m}$, and the dimensions of the room were from $3 \times 4$ to $4 \times 5 \mathrm{~m}$. While the lignite was removed, the ceiling was secured with a wooden support. That wood was stripped after the mining work was completed, which caused the overlayer to collapse. After the ceiling had collapsed, work on another room started [13,14].

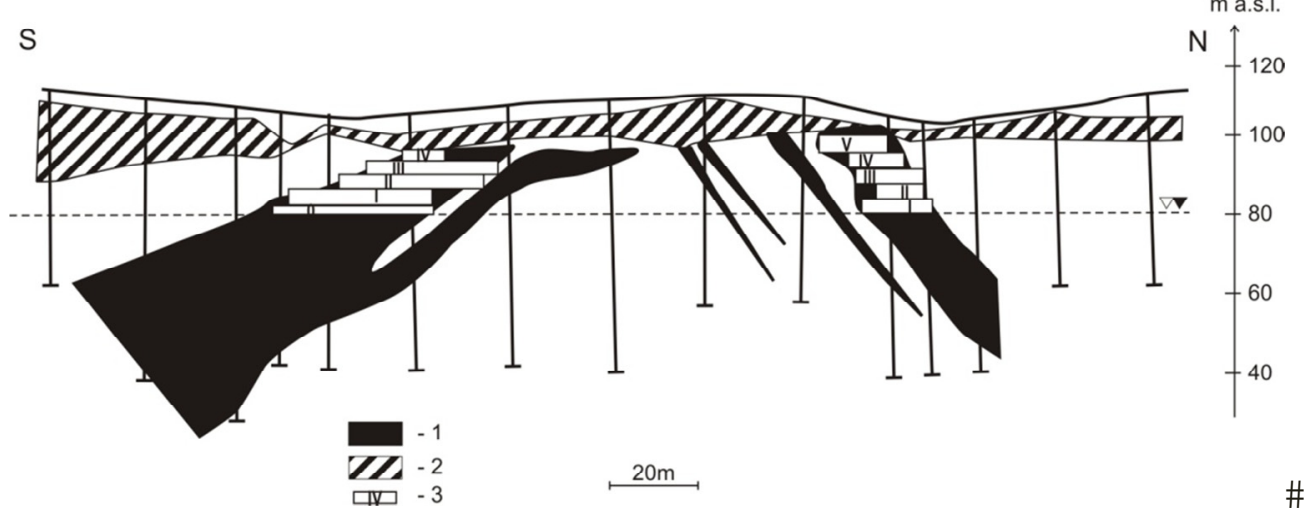

Fig. 2. A simplified geological cross-section of one of the folds of the "Smogóry" mine. 1 - lignite bed, 2 - till, 3 - mining level [10]

\section{The mine "Borussia" - preserved historical records}

The registration of the mining area "Oscars Segen" of 29 November 1855 is regarded as the beginning of the mine "Borussia". In 1874 the mine "Oscars Segen" was consolidated with other mines and mining areas and given the name of "Borussia" [13]. In the 1920 s the mine "Borussia" was included in the neighbouring mine "Oskar". 
Lignite was mined to the south and north of the railway line Ośno Lubuskie - Sulęcin (Fig.1., Fig.3.). The shafts marked as I and II can be seen on topographic maps (from 1899 and 1927), and shafts marked as $\mathrm{H}, \mathrm{K}$ and $\mathrm{J}$ on a geological map from 1905. No mining map with these shafts has been preserved. Shafts H, K and J were 30-40 m deep. In each of these shafts two beds were mined. Their thickness was about $3.0-3.5 \mathrm{~m}$ and they were separated from each other with a layer of sand with a thickness of about 8-10 m. There was one more bed below, which was mined only through shaft $\mathrm{H}$ [5]. It is quite possible that on the topographic maps the names were changed: shaft $\mathrm{H}$ to shaft II and shaft $\mathrm{J}$ to shaft I (Fig.3., Fig.4.).

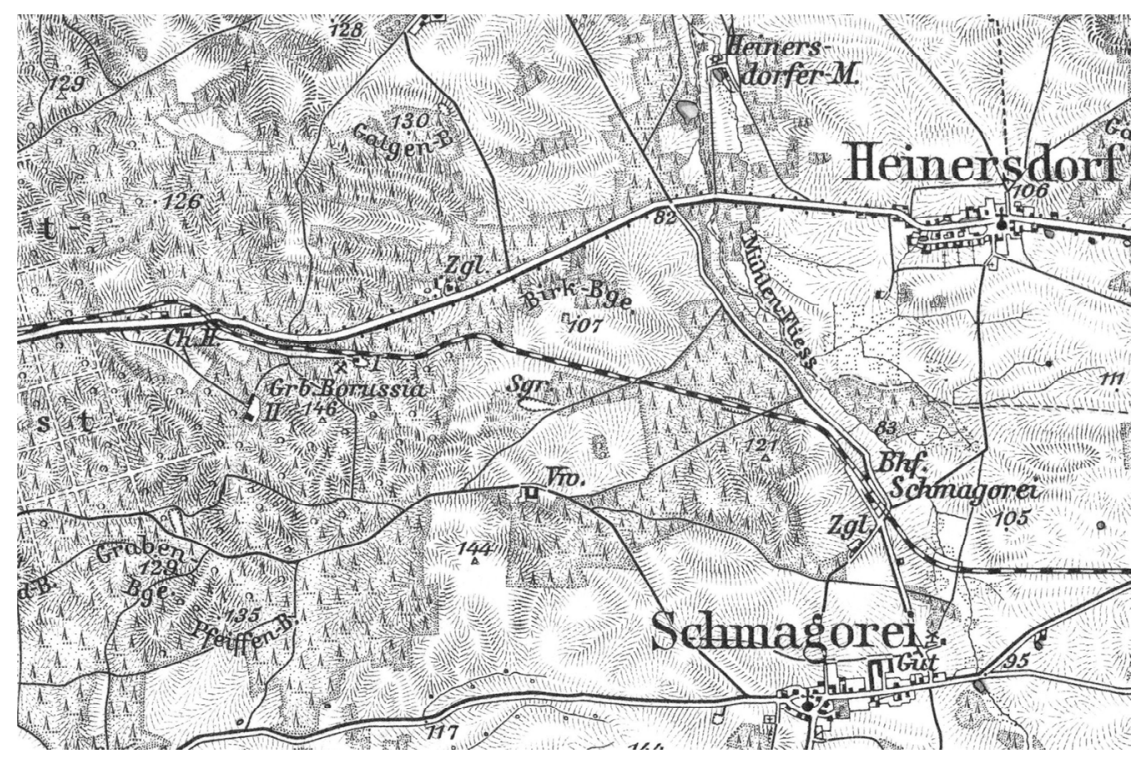

Fig.3. The map from 1899. Shaft I and II of "Borussia" mine are marked

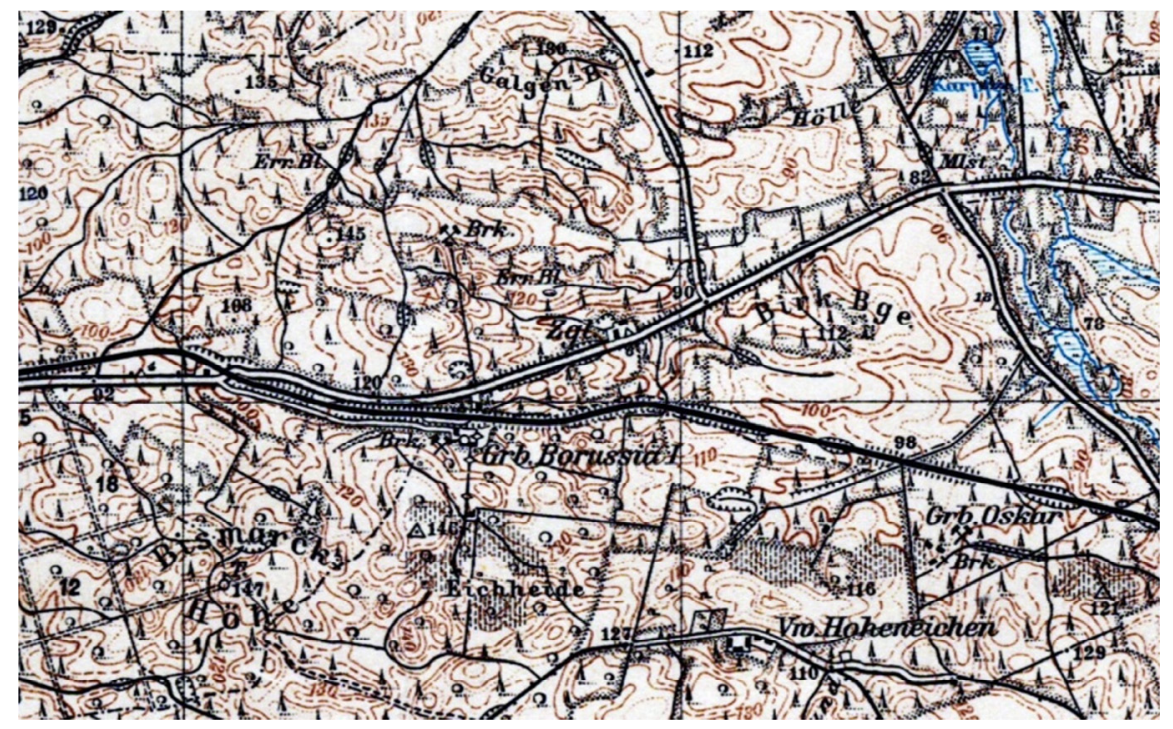

Fig. 4. The map from 1927. "Borussia" shafts: I and Otto are marked 
A German pre-WW2 geological map also mentions the location of saddles (folds) in the mining area of "Borussia" and shows other shafts. It is not known whether those shafts belonged to "Borussia" or to the other, smaller mines.

Detailed information has only been preserved about the lignite deposit mined through the shaft "Otto", which operated in the years 1924-1932. It was 46.39 meters deep and was located about $500 \mathrm{~m}$ north of the railway line. Two beds were mined in it: the lower one (II Flötz), whose main tunnel was located about 66-67 $\mathrm{m}$ above sea level and the upper one (I Flötz) with the main tunnel located about $91 \mathrm{~m}$ above sea level. Complete 1:1000 mining maps have been preserved for both beds. Apart from the shaft "Otto", the deposit was accessible by a descending gallery located in the eastern part of the bed.

The output from the shaft "Otto" was transported by rail to the railway siding where it was sifted and briquetted. The briquette factory was located directly south of the siding. The mined lignite deposit crossed the Ośno -Sulęcin road for which a safety pillar of about $40 \mathrm{~m}$ was built. Only transport tunnels were built near the safety pillar.

\section{Airborne laser scanning}

The ALS (Airborne laser scanning) is one of the remote sensing technologies [15,16].

The ALS (Airborne laser scanning) system consists of two segments: the on-board segment and the on-ground segment. The on-board system consists of a laser rangefinder, a plane positioning system based on the GNSS (Global Navigation Satellite System), the INS (Internal Navigation System), a digital camera, a data recorder and the FMS (Flight Management System). The on-ground segment includes: a land based GNSS reference station and specialist software, which makes it possible to process data obtained as a cloud of points. This technology is often called a laser radar or LiDAR (Light Detection And Ranging).

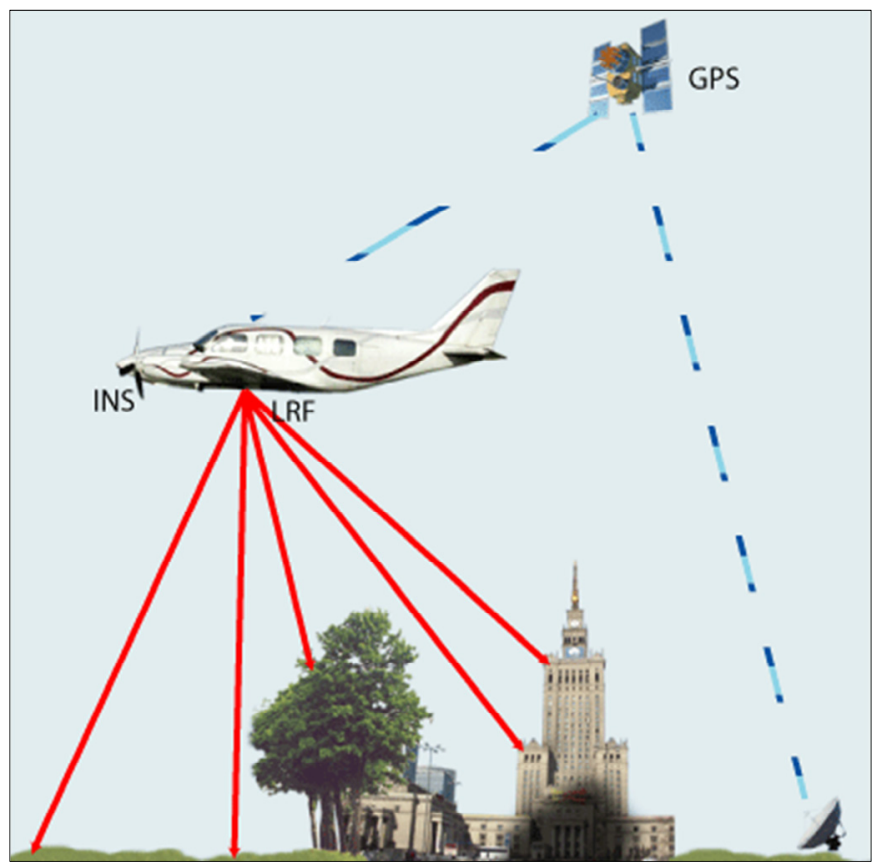

Fig. 5. The technique of airborne laser scanning, prepared by the author, based on [1] 
The technique of data acquisition by airborne laser scanning is based on laser measurements of the distance between points located on the terrain surface and a flying plane. For this purpose a laser rangefinder is used. The rangefinder is also connected to the GNSS, which makes it possible to find the position of the flying plane. Moreover, on the basis of the points obtained with the INS, the angle of inclination and the velocity of the platform with the scanner head are determined $[1,17]$. All this information makes it possible to determine the coordinates $(\mathrm{X}, \mathrm{Y}, \mathrm{H})$ of points located on the terrain surface (Fig. 5). A cloud of points obtained in this way, being a quasi-continuous metric terrain model including objects located over and on the terrain Surface, is an intermediate product (a starting point) for further analyses. In order to use the data obtained as a cloud of points, it is necessary to process them, and the basic method of processing a cloud is classification, which consists in assigning an attribute to each point. In this way points representing different categories can be separated from the whole, e.g. points located on the terrain surface, buildings, low, medium-height and high plants as well as other categories defined according to the user's needs. This approach makes it possible to prepare final products, which could be: digital elevation models: a digital land cover model (DLCM), a digital terrain model (DTM), spatial models of buildings, cities or vector maps e.g. of communication routes, coastal zones, watercourses or power lines.

\section{Research area}

The mining areas of the mine "Borussia" are known from the preserved topographic maps (mainly the location of the shafts), the mining maps, (only the deposit mined through the shaft "Otto") and the geological map. The geological map from 1905 shows the location of shafts (probably ones belonging to different mines) and the strike of the anticlines, which is consistent with the mined deposits (Fig. 6). As a result of the use of the room and pillar retreat mining method, very characteristic funnel-shaped sinkholes appear on the terrain surface. Near the villages of Smogóry and Trześniów rows of such sinkholes can be clearly seen. They precisely mark the mining area. The picture is more accurate in the case of the newer workings.

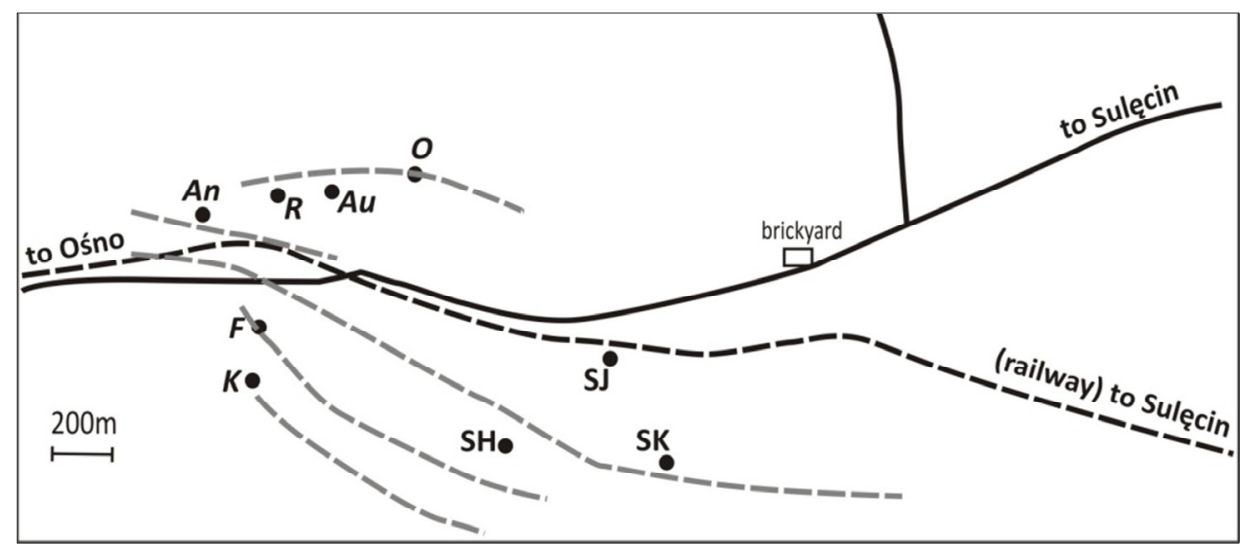

Fig. 6. A sketch of the "Borussia" mine surroundings, the end of the 19th century (based on the geological map). Mining areas: "Borussia" shafts: SH - shaft H, SK - shaft K, SJ - shaft J, other shafts (mines?): An - Andreas, R - Rudolf, Au - August, O - Otto, F - Franz, K - Konrad. The strikes of lignite anticlines have been marked [10]

The data obtained by airborne laser scanning made it possible to identify a number of details, including no longer existing structures. In the case of the shaft "Otto", it is possible 
to clearly see the former railway line connecting the shaft with the railway station and then with the briquette factory, as well as the location of the briquette factory itself (already demolished in the 1930s). It is also possible to see the descending gallery, which was located in the eastern part of the deposit (Fig.7,8).

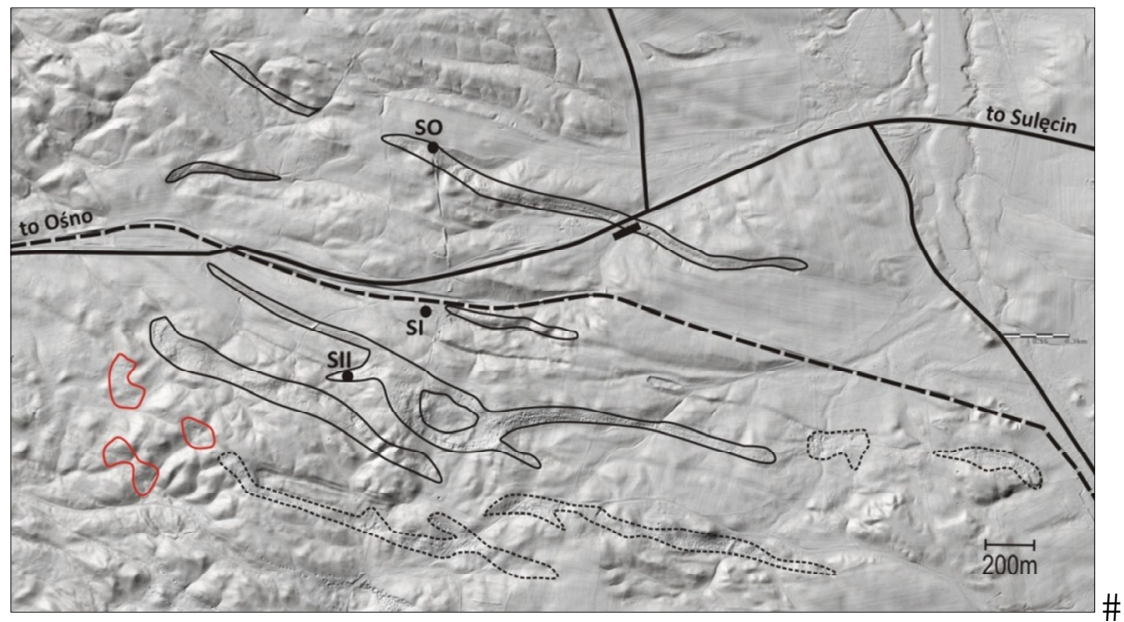

Fig. 7. A numerical terrain model of the mine "Borussia". Explanations: SO - shaft "Otto", SI - shaft I, SII- shaft II. The deformation areas corresponding to the mining area have been marked. The broken line marks the deposits mined by the mine "Oskar", the red line marks a probable mining area (19th century).

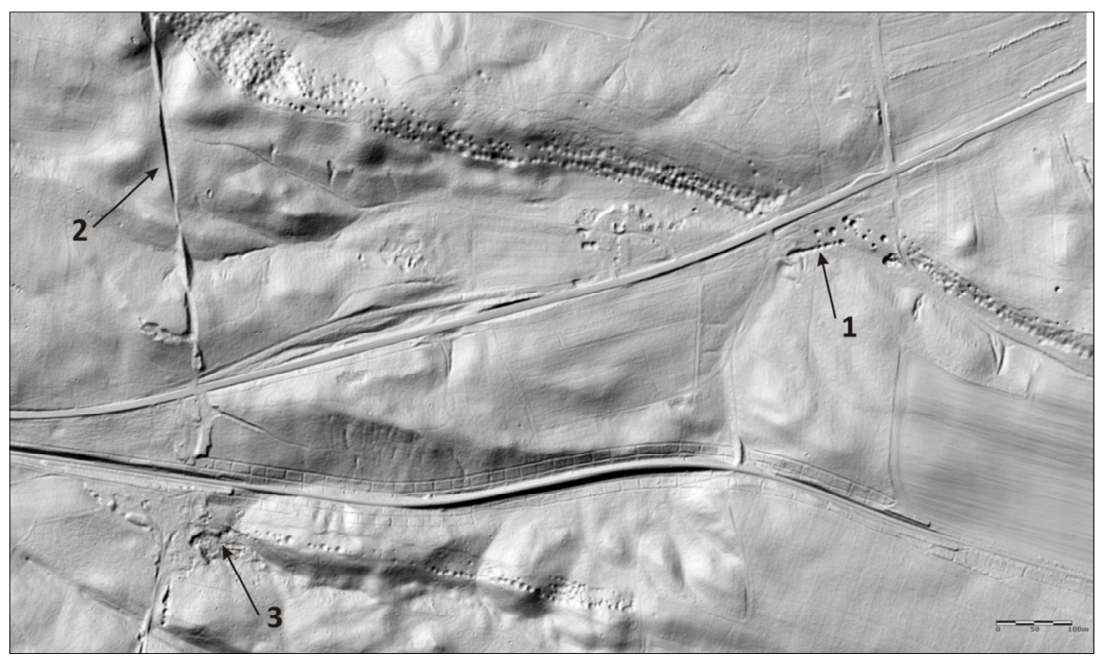

Fig. 8. A numerical terrain model of a part of the mine "Borussia" - Otto shaft. 1- descending gallery, 2 - railway between shaft and briquette factory and railway station, 3 - briquette factory

\section{Conclusion}

The above figures clearly show that airborne laser scanning can be very useful for identifying terrain deformations. This is particularly important in the case of places where direct measurements are difficult, such as forests. The room and pillar retreat mining method, which was used in the underground lignite mines in western Poland, caused very 
typical terrain deformations - a row of craters. They make it possible to precisely determine the mining area, both with traditional geodesic methods and by airborne laser scanning. The depressions formed in the 20th century in forests areas have been preserved in excellent condition, and the older deformations (from the 19th century) not so well, but it is still possible to identify them. Airborne laser scanning is a technology with a vast potential for identifying post-mining areas, in particular where historical data are missing. Data from airborne laser scanning require analytical instruments that enable data visualization as well as algorithms for processing clouds of points.

Data from airborne laser scanning make it possible to precisely represent terrain deformations in the form of a numerical terrain model, which undoubtedly is an advantage in the case of forest areas.

\section{References}

1. Kurczyński Z., Fotogrametria, Państwowe Wydawnictwo Naukowe, Warszawa (2014)

2. Plettner F., Die Braunkohle In der Mark Brandenburg. Ihre Verbreitung und Lagerung. Berlin (1852)

3. Cramer H., Beiträge zur Geschichte des Bergbaues in der Provinz Brandenburg, Heft 1, Kreis Sternberg, Halle, (1872)

4. Klein G., Handbuch für den deutschen Braunkohlenbergbau, I Band. Verlag von Wilhelm Knapp, Halle (1927)

5. Pietzsch K., Die Braunkohlen Deutschlands. Berlin (1925)

6. Poborski C., Geologia złóż węgla brunatnego. [in:]: Węgiel brunatny w Zachodniej Polsce, Katowice (1949)

7. Suszyński K., Przegląd Górniczy, 1-4 , 33-41 (1946)

8. Żaba J., Prace Naukowe Uniwersytetu Śląskiego 169, 108-142 (1977)

9. Gontaszewska A., Hereditas Minariorum, 2, 51-65 (2015)

10. Gontaszewska A., Zeszyty Naukowe Uniwersytetu Zielonogórskiego, 42, 89-101 (2016)

11. Mojski J.E., Ziemie polskie w czwartorzędzie. Państwowy Instytut Geologiczny, Warszawa (2005)

12. Urbański K., Zeszyty Naukowe Uniwersytetu Zielonogórskiego, 129, 159- 173 (2002)

13. Gontaszewska A., Przegląd Górniczy, 10, 1-8 (2015)

14. Grumprecht A., Grundlagen der Braunkohlenbergbau. Verlag Wilhelm Knapp, Halle (1948)

15. Pilecka E., Piątkowska A., Graniczny M., An application of the remote sensing technology to the high-energy seismic activity assessment, on the example of the Upper Silesian Coal Basin (USCB), Polish Geological Institute Special PapersVolume 20, 9298 (2005)

16. Pilecka E., Szwarkowski D., An application of the ground laser scanning to recognise terrain surface deformation over a shallowly located underground excavation, E3S Web of Conferences, Vol. 24, 1-8, (2017)

17. Wężyk P., Podręcznik dla uczestników szkoleń z wykorzystaniem produktów LiDAR Główny Urząd Geodezji i Kartografii, Warszawa (2014)

18. Jaros J., Słownik historyczny kopalń węgla na ziemiach polskich, Katowice (1984) 